\title{
Tobacco Smoking is Positively Associated with Hepatocellular Carcinoma Due to the p53 Mutation at Serine 249
}

Huai Wang ( $\square$ wonghuai@hotmail.com )

Nanchang University https://orcid.org/0000-0002-6624-6340

Lu Chen

Wuhan Taisheng Biological Technology Co., LTD

Tong Zhou

Nanchang University

Zhongwei Zhang

Nanchang University

Canwei Zeng

Wuhan Taisheng Biological Technology Co., LTD

\section{Research article}

Keywords: Tobacco smoking, Hepatocellular carcinoma, Mutant p53, Serine 249

Posted Date: September 23rd, 2020

DOI: https://doi.org/10.21203/rs.3.rs-45397/v1

License: (a) (1) This work is licensed under a Creative Commons Attribution 4.0 International License. Read Full License 


\section{Abstract}

Background The major risk factors for hepatocellular carcinoma (HCC) are known to be hepatitis b virus (HBV) infection and aflatoxin B1(AFB1) exposure. However, there is still controversy about whether smoking is related to HCC.

Methods A binary unconditional logistic regression was used for the data about a total of 300 cases and 612 controls. The approach of functional analysis of separated alleles in yeast (FASAY) was applied to analyze p53 status in HCC group. The relationship between p53 mutation at Serine 249 (p53-RS) and smoking was assessed. Quantitative reverse-transcription PCR (qRT-PCR) was employed for the evaluation to transcriptional activity of p53 and p53-RS.

Results Smoking was linked to the risk of HCC with an increased dose-response effect. Moreover, among subjects without alcohol drinker, the risks of HCC were significantly increased for smokers between HCC and controls. Besides, there was an increase in the number of HCC in smokers compared to non-smokers after exclusion of HBV and/or HCV infection. Also, a significant difference was observed about p53-RS between smokers and nonsmokers. Furthermore, the p53-RS transcriptional activity was significantly increased in tumor tissues.

Conclusions It demonstrated that tobacco smoking is positively and independently associated with HCC, which may be attributed to $\mathrm{p} 53-\mathrm{RS}$ and its gain of function.

\section{Background}

Hepatocellular carcinoma (HCC) accounts for $>80 \%$ of primary liver cancers, which is one of the most common and deadly cancers worldwide [1]. HCC causes a heavy disease burden and is the leading cause of cancer-related deaths in many parts of the world. It is estimated that HCC is the fourth most common cause of cancer-related deaths worldwide [2]. Even HCC is not the most common cancer in most parts of the world, and its high mortality rate (the incidence to mortality rate is 0.95 ) and short survival (5-year survival rate is only 6.9\%) create a serious global health burden [3]. Multiple risk factors leading to HCC have been well identified, including chronic HBV and/or HCV infections, carcinogen exposure (e.g. aflatoxin B1, AFB1), excessive alcohol consumption, and multiple genetic factors [4, 5].

Chronic HBV and HCV infections are the most important causes of liver cancer, accounting for $80 \%$ of global HCC cases [6]. Chronic HBV infection is a major cause of HCC in East Asia and most African countries, with the exception of North Africa, where HCV prevalence is highest $[7,8]$. HBV infections are usually obtained vertically from mothers to children in China and other parts of Asia, while sibling transmission is more common in Africa [9]. Overall, the annual incidence of HCC in patients with cirrhosis caused by chronic HBV or HCV infection is $2-5 \%$ [10].

Aflatoxins are difuranocoumarin derivatives of Aspergillus flavus and A. parasiticus. These fungal contamination occurs both during crop growth and due to the improper storage. High levels of exposure to fungal toxin are widely distributed in subSaharan Africa and the Asia-Pacific region. AFB1 is the aflatoxin most often found in contaminated human foodstuffs and is the most potent hepatocarcinogen [11]. One study confirmed the effectiveness of preventing post-harvest contamination through simple interventions such as drying crops on cloth rather than soil, hand sorting to remove moldy crops and better storage practices [12].

Heavy drinking ( $>80 \mathrm{~g} /$ day) for more than 10 years increases the risk of HCC by approximately 5 times [13]. Annual incidence of HCC in patients with alcoholic cirrhosis is 1-2\% [14]. Alcohol consumption and viral hepatitis have synergistic effects on HCC. Alcoholic cirrhosis is the second most common risk factor for liver cancer in the United States and Europe [15]. The World Cancer Research Fund conducted a meta-analysis of 19 studies [ $=5,650$ ] and found a statistically significant increase in risk of $4 \%$ per 10 grams of alcohol intake per day, with odds ratios (OR) being 1.04 and $95 \%$ confidence intervals (CI) being 1.02 to 1.06 , respectively [16]. 
However, the contribution of smoking to liver cancer risk remains unclear, unlike HBV and HCV infections, aflatoxin expression, and excessive drinking. Although smoking is also associated with HCC risk in case-control and cohort studies in different populations, the validity of such results is often questionable as a result of confounding effect of alcohol [17-19], which is often too closely correlated smoking. Similarly, in populations where HBV and HCV infection is endemic, it may be also difficult to rule out the infection as a confounding factor [20]. Moreover, HCC only develops in a small part of the exposed population, which means that genetic factors may contribute to the carcinogenic mechanism. In the present study, we also further sought to understand more fully the critical determinants for the carcinogenic activity of tobacco smoking. It showed a significant dose-response, positive association between smoking and HCC risk. Moreover, there was a statistically significant correlation between p53 mutations in serine 249(p53-RS) and smoking status.

\section{Methods}

\subsection{Study population}

The study had a hospital-based case-control design. Between June 2015 and December 2018, we enrolled 300 cases HCC, and those who were diagnosed within 1 year prior to admission were also regarded as eligible. HCC diagnosis is based primarily on pathology, cytology or an elevated alpha-fetoprotein levels $(400 \mathrm{ng} / \mathrm{ml})$ as well as positive results from at least two diagnostic imaging examinations, including angiography, ultrasound and computed tomography scans. The control group subjects were those who did not suffer from liver disease, such as chronic hepatitis or hepatic cirrhosis, as well as neoplasms and tobacco- or alcohol-related disease, and were genetically unrelated family member (i.e., spouses and in-laws) and matched for age (within the same 5-year age class), gender, residence (prefecture) and time of hospitalization (with 2 months after a case interview).

\subsection{Laboratory testing}

HBV and HCV were tested from the blood samples of the case $(n=300)$ and control group $(n=612)$. Hepatitis-B surface antigen (HBsAg) was detected by an immunoassay (Bio-Rad Laboratories, Redmond, WA). Antibody to hepatitis $\mathrm{C}$ virus (anti$\mathrm{HCV}$ ) was determined by a second-generation enzyme immunoassay (Bio-Rad Laboratories, Redmond, WA). Results were interpreted according to the manufacturer's instructions. Positive results prompted repeated confirmatory enzyme-linked immunosorbent assay testing. The technician who performed the blood test turned a blind eye to the identity of the participant and the disease. Peripheral blood samples, including white blood cells and serum, were collected from patients and controls and frozen at $-80^{\circ} \mathrm{C}$ until analysis.

\subsection{Questionnaire}

All HCC patients and hospital controls were interviewed in the hospital. Personal general information including age, gender, height, alcohol and smoking status was elicited during questionnaire-based interviews. Also, questionnaires were structured to obtain information on participants' weight before cancer diagnosis (HCC patients) or recruitment (control group). the body mass index (BMI) was estimated based on participants' weight $(\mathrm{kg})$ and height $(\mathrm{m})$. Drinkers are defined as individuals who drink any alcoholic beverage monthly or more often. Anyone who quit smoking more than three years before HCC onset is considered a former smoker. Those who quit smoking three years before the diagnosis are considered current smokers. Besides, former smokers were classified on basis of the number of smoking per day in the past, while current ones were classified in line with the daily number of cigarettes smoked before the onset of HCC or a corresponding date in the controls.

\section{4. p53 determination}

All patients underwent complete hepatectomy. In each case, tumor fragments and corresponding normal tissues were obtained and partially frozen in liquid nitrogen and stored at $-80^{\circ} \mathrm{C}$, until further testing of p53 transcriptional activity to prevent RNA degradation. The remaining tumor materials were fixed in buffered formalin (10\%), embedded in paraffin and sliced, followed by staining with hematoxylin-eosin for pathological evaluation. Pathological classification, including tumor 
grade and staging, was assessed on the basis of the world health organization system and TNM classification [21], respectively.

The functional status of p53 gene was determined by the functional analysis of separated alleles in yeast (FASAY) method described previously [22]. Briefly, according to the manufacturer's instructions, use the RNeasy Mini kit to extract total RNA from the tumor material, and then reverse transcribe the RNA sample at $37^{\circ} \mathrm{C}$. PCR amplified p53cDNA with the following primers: 5'-CCT TGC CGT CCC AAG CAA TGG ATG AT-3' for P3 and 5'-ACC CTT TTT GGA CTT CAG GTG GCT GGA GT-3' for P4 (Invitrogen, Carlsbad, CA, USA) and Pfu DNA Polymerase (Stratagene). The crude polymerase chain reaction product and linearized p53 expression vector were co-transfected into the yIG397 of yeast reporter strain. The transformed yeast cells were plated on a minimal medium without leucine and incubated with a small amount of adenine $(5 \mu \mathrm{g} / \mathrm{ml})$ at $35^{\circ} \mathrm{C}$ for $2-3$ days and then at room temperature for 2-3 days. The experiment was repeated at least twice to determine the average percentage of red colonies. p53 status was considered mutated on the basis of the following criteria from Lehmann-Che et al [23]: (a) more than $10 \%$ of the yeast colonies were red, (b) defects in the $5^{\prime}$ or 3 ' section of the gene can be identified through analysis of the split versions of the test, and (c) sequence analysis of mutant yeast colonies can identify clear genetic defects. Sequencing the presence of more than four clonal mutations in yeast colonies was the final criterion for defining mutations.

\subsection{RNA isolation and quantitative reverse-transcription PCR (qRT-PCR) analysis}

Following the manufacturer's instructions, RNA kit was used for the extraction of samples from freshly frozen tumor tissue and normal non-tumor mucosa (RNeasy Lipid Tissue Qiagen kit, 74804; Qiagen, Valencia, CA). qRT-PCR was done using IQ SYBR green (Bio-Rad, USA) and GAPDH as reference gene. The relative expression of mRNA was determined by the comparative Ct Method ( $\triangle \Delta C$ t method). Each sample was analyzed in triplicate by qRT-PCR. The designed primer sequences were as follows:

5'-GAG ACA CCA CTG GAG GGT GAC TTC G-3' and 5'-GGG CAA ACA ACA GAT GGC TGG CAA C-3' for human p21; 5'-GAG GAT GAT TGC CGC CGT GGA CA-3' and 5'-GGT GGG GGA GGA GGC TTG AGG-3' for human Bax; 5'-AAA ACT AGT CGA CGA TGC CCC TCA ACG TTA GC-3' and 5'-AAA AAG CTT GGT CGG CCG TGG AGA AGC TCC C-3' for human c-Myc; 5'-CGC GCA TGC AAG TGG CAT ATA ACT-3' and 5'-AAG CTC GAA CCA CTG TGA CAT CCT-3' for human STAT1; 5'-GAG TCA ACG GAT TTG GTC GT-3' and 5'-GAC AAG CTT CCC GTT CTC AG-3' for human GAPDH.

\subsection{Statistical analysis}

All statistical analyses were performed through SPSS for Windows (version 25.0, Chicago, IL). Differences between the cases and controls in the distributions of demographic characteristics were accessed by Chi-square test (qualitative data) and an unpaired two-tailed Student's t-test (quantitative data). Also, using hierarchical analysis and unconditional Logistic regression model to generate OR with $95 \% \mathrm{Cl}$ for HCC risk as relative risk estimation [24]. Because it is impossible for some HCC cases to match individual, it is necessary to carry out unconditional logistic regression model instead of the conditional, with adjusting the matching factors. Likelihood ratio test is the difference between maximum logarithmic and likelihood statistics, and it is used to evaluate the significance of additional covariates in the model [24]. All $p$-values quoted were two-sided and significant differences were considered at a $p<0.05$.

\section{Results}

\subsection{Tobacco smoking and its interaction in the causation of HCC}

The distribution of factors including demographic characteristics of chronic HBV infection, HCV infection and serological evidence between HCC cases and hospital controls, as well as smoking status and alcohol consumption, was showed in Supplementary Table 1. Cases and controls were similarly distributed by age, gender and body mass index. There were, as 
expected, significant differences $(p<0.05)$ in gender status and prevalence of HBV and HCV infection markers, because these are the main reasons for HCC. Also, it was interestingly found that smokers were significantly more likely to the causation of HCC than non-smokers $\left(\chi^{2}=67.131, p=0.000\right)$ and smoking was more common among cases than among controls.

We examined the cigarette smoking-HCC association. Table 1 showed the distribution of HCC cases and hospital controls by smoking habits. The distributions were gender-specific, owing to the expected differences about these activities in terms of prevalence by gender. Smokers were significantly associated with HCC. The corresponding estimates were $3.500(95 \% \mathrm{Cl}=$ $2.518-4.866)$ and $2.962(95 \% \mathrm{Cl}=2.014-4.355)$ for current smokers and former smokers. In terms of dose, there appeared to be a dose-response relationship between HCC and quantity smoked with adjusted OR estimates of 3.267 and 4.375 for smoking $<2$ packs per day and $\geq 2$ packs per day for current smoker, respectively. Likewise, significant OR variation was found when considering only a group of subjects among former smoker, the ORs for $<2$ packs per day and $\geq 2$ packs per day being $2.450(95 \% \mathrm{Cl}=1.572-3.817)$ and $4.667(95 \% \mathrm{Cl}=2.451-8.885)$, respectively. Altogether, it demonstrated that smoking was associated with an increased risk of HCC according to the adjustment of age and gender, but mutual confounding precludes alcohol intake and valid etiological inferences.

Table 1

Gender-specific distribution of HCC cases and hospital controls by smoking habit, with OR and $95 \% \mathrm{Cl}$

\begin{tabular}{|c|c|c|c|c|c|}
\hline & \multicolumn{2}{|c|}{ HCC cases $(n=300)$} & \multicolumn{2}{|c|}{ Hospital controls $(n=612)$} & \multirow[t]{2}{*}{ OR $(95 \% \mathrm{Cl})$} \\
\hline & $\begin{array}{l}\text { Men }(n= \\
198)\end{array}$ & $\begin{array}{l}\text { Women }(n= \\
102)\end{array}$ & $\begin{array}{l}\text { Men }(n= \\
468)\end{array}$ & $\begin{array}{l}\text { Women }(n= \\
144)\end{array}$ & \\
\hline \multicolumn{6}{|l|}{$\begin{array}{l}\text { Smoking status } \\
\text { (packs/day) }\end{array}$} \\
\hline Never smoker (\%) & $54(27.27)$ & $66(64.70)$ & $288(61.54)$ & $132(91.67)$ & 1.000 \\
\hline Current smoker (\%) & $90(45.45)$ & $24(23.53)$ & $108(23.08)$ & $6(4.17)$ & $\begin{array}{l}3.500(2.518- \\
4.866)\end{array}$ \\
\hline$<2$ & 66 (33.33) & $18(17.65)$ & $84(17.95)$ & $6(4.17)$ & $\begin{array}{l}3.267(2.279- \\
4.682)\end{array}$ \\
\hline$\geq 2$ & $24(12.12)$ & $6(5.88)$ & $24(5.13)$ & $0(0.00)$ & $\begin{array}{l}4.375(2.465- \\
7.766)\end{array}$ \\
\hline Former smoker (\%) & $54(27.27)$ & $12(11.76)$ & $72(15.39)$ & $6(4.17)$ & $\begin{array}{l}2.962(2.014- \\
4.355)\end{array}$ \\
\hline$<2$ & $36(18.18)$ & $6(5.88)$ & $54(11.54)$ & $6(4.17)$ & $\begin{array}{l}2.450(1.572- \\
3.817)\end{array}$ \\
\hline$\geq 2$ & $18(9.09)$ & $6(5.88)$ & $18(3.85)$ & $0(0.00)$ & $\begin{array}{l}4.667(2.451- \\
8.885)\end{array}$ \\
\hline
\end{tabular}

We further explored the independent and combined effects of smoking and alcohol consumption on HCC risk stratified by age, sex, and body mass index. The distribution of cases and controls by smoking status and the adjusted risks of HCC in relation to smoking status by alcohol intake are shown in Table 2. Compared with never smokers, current and former smokers both had an increased HCC risk of significance. Interestingly, subjects with alcohol drinker had a significantly increased risk. Moreover, stratification revealed that subjects without alcohol drinker had a significant dose-response increase in HCC disease risk. The overall risks of HCC were significantly increased among current smokers smoking $<2$ packs per day (OR = 2.800, $95 \% \mathrm{Cl}=1.933-4.055)$ between HCC patients and controls, and these risks were of similar magnitude among subjects without alcohol drinker, with an estimated effect much higher than that for never smokers $(\mathrm{OR}=2.895,95 \% \mathrm{Cl}=1.640-$ 5.110). Compared with current smokers, former smokers had significant increases in the risk of HCC overall (<2 packs per day, $\mathrm{OR}=3.150,95 \% \mathrm{Cl}=2.070-4.794)$ and by subtype of non-alcohol drinking ( $<2$ packs per day, $\mathrm{OR}=2.316,95 \% \mathrm{Cl}=$ $1.341-4.001)$. 
Table 2

Multiple regression-derived mutually adjusted OR $(95 \% \mathrm{Cl})$ for the association of HCC with smoking habit, by alcohol intake *

\begin{tabular}{|c|c|c|c|c|c|c|c|c|c|}
\hline & \multicolumn{3}{|c|}{ All subjects } & \multicolumn{3}{|c|}{$\begin{array}{l}\text { Subjects without alcohol } \\
\text { drinker }\end{array}$} & \multicolumn{3}{|c|}{ Subjects with alcohol drinker } \\
\hline & $\begin{array}{l}\text { Cases } \\
(n= \\
300)\end{array}$ & $\begin{array}{l}\text { Controls } \\
(n= \\
612)\end{array}$ & $\begin{array}{l}\text { OR } \\
(95 \% \mathrm{Cl})\end{array}$ & $\begin{array}{l}\text { Cases } \\
(n= \\
160)\end{array}$ & $\begin{array}{l}\text { Controls } \\
(n= \\
306)\end{array}$ & $\begin{array}{l}\text { OR } \\
(95 \% \mathrm{Cl})\end{array}$ & $\begin{array}{l}\text { Cases } \\
(n= \\
140)\end{array}$ & $\begin{array}{l}\text { Controls } \\
(n= \\
306)\end{array}$ & $\begin{array}{l}\text { OR } \\
(95 \% \mathrm{Cl})\end{array}$ \\
\hline \multicolumn{10}{|l|}{$\begin{array}{l}\text { Smoking } \\
\text { status } \\
\text { (packs/day) }\end{array}$} \\
\hline $\begin{array}{l}\text { Never } \\
\text { smoker (\%) }\end{array}$ & $\begin{array}{l}120 \\
(40.00)\end{array}$ & $\begin{array}{l}420 \\
(68.63)\end{array}$ & 1.000 & $\begin{array}{l}68 \\
(42.50)\end{array}$ & $\begin{array}{l}210 \\
(68.63)\end{array}$ & 1.000 & $\begin{array}{l}52 \\
(37.15)\end{array}$ & $\begin{array}{l}210 \\
(68.63)\end{array}$ & 1.000 \\
\hline $\begin{array}{l}\text { Current } \\
\text { smoker (\%) }\end{array}$ & $\begin{array}{l}114 \\
(38.00)\end{array}$ & $\begin{array}{l}126 \\
(20.59)\end{array}$ & $\begin{array}{l}3.167 \\
(2.289- \\
4.381)\end{array}$ & $\begin{array}{l}50 \\
(31.25)\end{array}$ & $\begin{array}{l}50 \\
(16.34)\end{array}$ & $\begin{array}{l}3.088 \\
(1.915- \\
4.981)\end{array}$ & $\begin{array}{l}64 \\
(45.71)\end{array}$ & $\begin{array}{l}76 \\
(24.84)\end{array}$ & $\begin{array}{l}3.401 \\
(2.168- \\
5.335)\end{array}$ \\
\hline$<2$ & $\begin{array}{l}72 \\
(24.00)\end{array}$ & $\begin{array}{l}90 \\
(14.71)\end{array}$ & $\begin{array}{l}2.800 \\
(1.933- \\
4.055)\end{array}$ & $\begin{array}{l}30 \\
(18.75)\end{array}$ & $\begin{array}{l}32 \\
(10.46)\end{array}$ & $\begin{array}{l}2.895 \\
(1.640- \\
5.110)\end{array}$ & $\begin{array}{l}42 \\
(30.00)\end{array}$ & $\begin{array}{l}58 \\
(18.96)\end{array}$ & $\begin{array}{l}2.924 \\
(1.774- \\
4.821)\end{array}$ \\
\hline$\geq 2$ & $\begin{array}{l}42 \\
(14.00)\end{array}$ & $\begin{array}{l}36 \\
(5.89)\end{array}$ & $\begin{array}{l}4.083 \\
(2.504- \\
6.660)\end{array}$ & $\begin{array}{l}20 \\
(12.50)\end{array}$ & $\begin{array}{l}18 \\
(5.88)\end{array}$ & $\begin{array}{l}3.431 \\
(1.716- \\
6.862)\end{array}$ & $\begin{array}{l}22 \\
(15.72)\end{array}$ & $\begin{array}{l}18 \\
(5.88)\end{array}$ & $\begin{array}{l}4.936 \\
(2.468- \\
9.870)\end{array}$ \\
\hline $\begin{array}{l}\text { Former } \\
\text { smoker (\%) }\end{array}$ & $\begin{array}{l}66 \\
(22.00)\end{array}$ & $\begin{array}{l}66 \\
(10.78)\end{array}$ & $\begin{array}{l}3.500 \\
(2.353- \\
5.205)\end{array}$ & $\begin{array}{l}42 \\
(26.25)\end{array}$ & $\begin{array}{l}46 \\
(15.03)\end{array}$ & $\begin{array}{l}2.820 \\
(1.711- \\
4.648)\end{array}$ & $\begin{array}{l}24 \\
(17.14)\end{array}$ & $\begin{array}{l}20 \\
(6.53)\end{array}$ & $\begin{array}{l}4.846 \\
(2.488- \\
9.438)\end{array}$ \\
\hline$<2$ & $\begin{array}{l}54 \\
(18.00)\end{array}$ & $\begin{array}{l}60 \\
(9.80)\end{array}$ & $\begin{array}{l}3.150 \\
(2.070- \\
4.794)\end{array}$ & $\begin{array}{l}30 \\
(18.75)\end{array}$ & $\begin{array}{l}40 \\
(13.07)\end{array}$ & $\begin{array}{l}2.316 \\
(1.341- \\
4.001)\end{array}$ & $\begin{array}{l}24 \\
(17.14)\end{array}$ & $\begin{array}{l}20 \\
(6.53)\end{array}$ & $\begin{array}{l}4.846 \\
(2.488- \\
9.438)\end{array}$ \\
\hline$\geq 2$ & $\begin{array}{l}12 \\
(4.00)\end{array}$ & $6(0.98)$ & $\begin{array}{l}7.000 \\
(2.573- \\
19.042)\end{array}$ & $\begin{array}{l}12 \\
(7.50)\end{array}$ & $6(1.96)$ & $\begin{array}{l}6.176 \\
(2.233- \\
17.084)\end{array}$ & $\begin{array}{l}0 \\
(0.00)\end{array}$ & $0(0.00)$ & $N / A^{* *}$ \\
\hline * Also contro & ng for ag & gender, bo & $y$ mass in & nd alcoh & intake stat & Is, as appr & & & \\
\hline
\end{tabular}

Besides, it showed multiple regression-derived, mutually adjusted OR (and 95\% Cl) for HCC association with cigarette consumption patterns in Table 3. Because the latency of a possible smoking associated with HCC had not yet been determined, we chose to study the impact of daily smoking, regardless of the current or previous smoking status. Data were shown for all subjects, and also were stratified according to serological evidence of HBV and/or HCV infection. Compared with never smokers, the relative risk of HCC for ever-smokers was estimated to be 3.281 ( $95 \% \mathrm{Cl}=2.462-4.373)$. Risk was also higher among HBsAg and anti-HCV negative participants, among whom the relative risk of $\mathrm{HCC}$ was $2.145(95 \% \mathrm{Cl}=$ 1.415-3.251) compared with never smokers. Also, it indicated a dose-response relationship with number of cigarettes smoked per day between smoking and HCC overall risk ( $<2$ packs per day, $\mathrm{OR}=2.940,95 \% \mathrm{Cl}=2.152-4.016$; $\geq 2$ packs per day, $\mathrm{OR}=4.500,95 \% \mathrm{Cl}=2.865-7.067)$, which was positively correlated. Besides, as far as smoking was concerned, the association with $\mathrm{HCC}$ risk was stronger in individuals without chronic viral infection than those never smokers ( 2 packs per day, $\mathrm{OR}=1.727,95 \% \mathrm{Cl}=1.090-2.738 ; \geq 2$ packs per day, $\mathrm{OR}=3.855,95 \% \mathrm{Cl}=2.021-7.351)$. These data convincingly 
suggested a super-multiplicative, interactive effect of smoking in the development of HCC in a statistically significant, dosedependent manner.

Table 3

Multiple regression-derived mutually adjusted OR $(95 \% \mathrm{Cl})$ for the association of $\mathrm{HCC}$ with smoking habit, by HBsAg and/or anti-HCV status ${ }^{*}$

\begin{tabular}{|c|c|c|c|c|c|c|c|c|c|}
\hline & \multicolumn{3}{|c|}{ All subjects } & \multicolumn{3}{|c|}{$\begin{array}{l}\text { Subjects without both HBsAg } \\
\text { and anti-HCV }\end{array}$} & \multicolumn{3}{|c|}{$\begin{array}{l}\text { Subjects with HBsAg and/or } \\
\text { anti-HCV }\end{array}$} \\
\hline & $\begin{array}{l}\text { Cases } \\
(\mathrm{n}= \\
300)\end{array}$ & $\begin{array}{l}\text { Controls } \\
(n= \\
612)\end{array}$ & $\begin{array}{l}\text { OR } \\
(95 \% \mathrm{Cl})\end{array}$ & $\begin{array}{l}\text { Cases } \\
(n= \\
128)\end{array}$ & $\begin{array}{l}\text { Controls } \\
(n= \\
324)\end{array}$ & $\begin{array}{l}\text { OR } \\
(95 \% \mathrm{Cl})\end{array}$ & $\begin{array}{l}\text { Cases } \\
(n= \\
172)\end{array}$ & $\begin{array}{l}\text { Controls } \\
(n=288)\end{array}$ & $\begin{array}{l}\text { OR } \\
(95 \% \mathrm{Cl})\end{array}$ \\
\hline \multicolumn{10}{|l|}{$\begin{array}{l}\text { Smoking } \\
\text { (packs } \\
\text { per day) }\end{array}$} \\
\hline $\begin{array}{l}\text { Never } \\
\text { smokers } \\
(\%)\end{array}$ & $\begin{array}{l}120 \\
(40.00)\end{array}$ & $\begin{array}{l}420 \\
(68.63)\end{array}$ & 1.000 & $\begin{array}{l}60 \\
(46.87)\end{array}$ & $\begin{array}{l}212 \\
(65.43)\end{array}$ & 1.000 & $\begin{array}{l}60 \\
(34.88)\end{array}$ & $\begin{array}{l}208 \\
(72.22)\end{array}$ & 1.000 \\
\hline $\begin{array}{l}\text { Ever } \\
\text { smokers } \\
(\%)\end{array}$ & $\begin{array}{l}180 \\
(60.00)\end{array}$ & $\begin{array}{l}192 \\
(31.37)\end{array}$ & $\begin{array}{l}3.281 \\
(2.462- \\
4.373)\end{array}$ & $\begin{array}{l}68 \\
(53.13)\end{array}$ & $\begin{array}{l}112 \\
(34.57)\end{array}$ & $\begin{array}{l}2.145 \\
(1.415- \\
3.251)\end{array}$ & $\begin{array}{l}112 \\
(65.12)\end{array}$ & $\begin{array}{l}80 \\
(27.78)\end{array}$ & $\begin{array}{l}4.853 \\
(3.234- \\
7.284)\end{array}$ \\
\hline$<2$ & $\begin{array}{l}126 \\
(42.00)\end{array}$ & $\begin{array}{l}150 \\
(24.51)\end{array}$ & $\begin{array}{l}2.940 \\
(2.152- \\
4.016)\end{array}$ & $\begin{array}{l}44 \\
(34.38)\end{array}$ & $\begin{array}{l}90 \\
(27.78)\end{array}$ & $\begin{array}{l}1.727 \\
(1.090- \\
2.738)\end{array}$ & $\begin{array}{l}82 \\
(47.68)\end{array}$ & $60(20.83)$ & $\begin{array}{l}4.738 \\
(3.052- \\
7.354)\end{array}$ \\
\hline$\geq 2$ & $\begin{array}{l}54 \\
(18.00)\end{array}$ & $\begin{array}{l}42 \\
(6.86)\end{array}$ & $\begin{array}{l}4.500 \\
(2.865- \\
7.067)\end{array}$ & $\begin{array}{l}24 \\
(18.75)\end{array}$ & $\begin{array}{l}22 \\
(6.79)\end{array}$ & $\begin{array}{l}3.855 \\
(2.021- \\
7.351)\end{array}$ & $\begin{array}{l}30 \\
(17.44)\end{array}$ & $20(6.95)$ & $\begin{array}{l}5.200 \\
(2.757- \\
9.808)\end{array}$ \\
\hline
\end{tabular}

\subsection{FASAY for detection of p53 mutations}

p53 gene mutation is one of the most common genetic changes in human cancer. The advantage of these mutations (95\%) is missense mutations, which are mainly located in the DNA binding domain (amino acids 94-292), with hot spots at codons $\mathrm{R} 175, \mathrm{G} 245, \mathrm{R} 248, \mathrm{R} 249, \mathrm{R} 273$ and R282 $[25,26]$. FASAY was proved to reach the highest sensitivity and specificity of p53 mutation detection [27, 28], due to the fact that a larger region of p53 gene in exon 4-10 was tested. Then mutations can be detected in a large number of normal tissues, because there are hundreds of clones in each sample, and simple red and white readouts mean mutations are not easy to ignore [29]. In addition, FASAY can exclude p53 polymorphisms that do not affect their transcriptional activity [30]. To detect the status of p53 in HCC tumors, the tumor mucosa of 300 patients was FASAY examined (Supplementary Table 2). In total, 228 tumors (76.00\%) were positive (mutant) by FASAY. Besides, analysis of plasmid sequencing from red yeast colony showed that 210 of 228 plasmids were point missense mutations, and 6 of 228 was frameshift deletion mutation, as well as 9 of 228 were in-frameshift deletion mutations, and 3 of 228 were splicing mutations (Fig. 1A). Moreover, hotspot mutation p53-RS that occurred 126 times in this study, accounting for $55.26 \%$ in total mutations. We further evaluated the relation between tobacco smoking and p53-RS mutation. A striking increase in the risk of p53-RS was observed for smokers (Fig. 1B). Furthermore, these differences about p53-RS between smokers and nonsmokers were statistically significant by Chi-square test $\left(56.67 \%\right.$ versus $\left.20.00 \% ; \chi^{2}=38.246, p=0.000\right)$. These results suggested that p53-RS mutation might be associated with the response to cigarette smoking. We also sought to determine whether the presence of p53-RS has a measurable effect on the expression of p53 major transcriptional targets ( 221 and Bax), as well as p53-RS-dependent target genes including c-Myc [31] and STAT1 [32] by using qRT-PCR on mRNA from fresh frozen components. For p21 and Bax, we found a decreased profile in p53-RS group compared with the WT p53 group (Figs. 1C and 
1D). However, in contrast to WT p53 group, we observed an increased expression about c-Myc and STAT1 in the tumors with p53-RS, showing a loss of transcriptional p53 function and p53-RS gain-of-function (Figs. 1E and 1F).

\section{Discussion}

Whether smoking is a risk factor for HCC is currently controversial. Although an increased risk of HCC is observed in smokers, there are no significant difference [33]. Besides, researches also report that smoking is a potential risk factor for HCC [18]. However, it is limited about exploration of the combined effects of these exposures such as HBV and HCV infection, and alcohol consumption. Synergism among these common factors would have substantial clinical relevance to smoking because it would place some individuals at extremely high risk. Thus, our goal is to carry out a clear examination to independently influence of the smoking on liver cancer in this study, without any alternative influence on HBV and HCV infection, as well as alcohol consumption.

Indeed, our results also indicated that HBV and HCV infection, and alcohol consumption increase the risk for liver cancer. This observed association was in agreement with those of most recent studies on this topic [34]. it was also shown that smoking is an independent risk factor for HCC in the present study (Table 1). Moreover, smokers who did not consume alcohol on a daily basis were shown to exhibit an at least 2.316-fold increased risk of HCC (Current smoker: $<2$ packs per day, OR $=2.895$; $\geq 2$ packs per day, $\mathrm{OR}=3.431$; Former smoker: $<2$ packs per day, $\mathrm{OR}=2.316, \geq 2$ packs per day, $\mathrm{OR}=6.176, \mathrm{Table} 2)$. Also, we found evidence that smoking is an important cause of HCC in people with non-chronic HBV or HCV infections (<2 packs per day, $\mathrm{OR}=1.727 ; \geq 2$ packs per day, $\mathrm{OR}=3.855$, Table 3$)$. However, $\mathrm{HCC}$ develops in only a few exposed populations and the complex interactions between many genetic and environmental factors may be the major cause of HCC.

p53 is a well-known tumor suppressor gene whose mutation plays an important role in the pathogenesis of HCC. Moreover, it is suggested that p53-RS mutant protein products may have specific biological effects that promote hepatocyte transformation and/or liver cancer progression, resulting to the selection of cells expressing this mutant during HCC [35]. FASAY can use yeast cell yIG397 to evaluate the functional status of p53 protein expressed in tumor cells, thereby detecting important functional mutations of p53 as a transcription factor. Also, the assessment of p53 transcriptional activity by FASAY in cancer cells has recently emerged as a useful valuable alternative to p53 nuclear overexpression [36]. Furthermore, it is validated the assay as a new tool in mutagenesis research can be used to study the mutagenicity on the origin of the codon 249 hot spot of p53 mutation [37]. Remarkably, our studies showed the various types of p53 mutations in HCC by FASAY in the current work, and that most of them were p53-RS, accounting for $55.26 \%$ in total mutations (Supplementary Table 2). Moreover, it demonstrated the strikingly relation between tobacco smoking and p53-RS (Fig. 1B, $p<0.001$ ). Also, at the functional level, the effect what we observed was the decrease of expression of p21 and Bax at the mRNA level in many mutated tumors as a direct consequence of the p53-RS, whereas the mRNA levels of the p53-RS targets (c-Myc and STAT1) seemed to be increased (Figs. 1C-1F). Altogether, it strongly demonstrated tobacco smoke as a causal factor of HCC development, which was attributed to p53-RS gain of function.

However, several limitations should be considered. First, our research enrolled the population by convenience sampling, which cannot represent the whole population in China, even in the world. Second, variables such as alcohol status is not available in the data, which is considered as potential risk factors of HCC.

\section{Conclusions}

Our results suggested that tobacco smoking is associated with HCC, independent from other major HCC risk factors, and this dose-response association was positive significantly. Besides, the present investigation indicated, that the p53-RS might confer genetic susceptibility that influences HCC development especially in smoker's patients. Based on these findings, it is conceivable that smokers have a high potential for HCC, who should receive clinical monitoring to p53-RS, and even treatment. 


\section{Abbreviations}

HCC: hepatocellular carcinoma; HBV: hepatitis B virus; HCV: hepatitis C virus; AFB1: aflatoxin B1; FASAY: functional analysis of separated alleles in yeast; p53-RS: p53 mutation at Serine 249; qRT-PCR: quantitative reverse-transcription PCR; OR: odds ratios; Cl: confidence intervals; HBsAg: hepatitis-B surface antigen; anti-HCV: antibody to hepatitis $\mathrm{C}$ virus; BMI: body mass index

\section{Declarations}

\section{Ethics approval and consent to participate}

Each participating study has been approved by the local ethic committee (Ethical Committee of Wuhan Hannan District People's Hospital with the following reference number: HN-2015-0606). The authors assert that all procedures performed in studies involving human participants were in accordance with the ethical standards of the relevant national and institutional committees on human experimentation and with the Helsinki Declaration of 1975, as well as its later amendment in 2008. Also, written consent was obtained from all participants in the study.

\section{Consent for publication}

Not applicable.

\section{Availability of data and materials}

The datasets generated and/or analyzed during the current study are not publicly available due to privacy reasons, but are available from the corresponding author on reasonable request.

\section{Competing interests}

The authors declare that they have no competing interests.

\section{Funding}

This work was supported by the Program of Natural Science Foundation of Jiangxi Province of China (NO. 20171BAB215076; NO. 20181BAB205089); and Research and Development Fund for Young Teachers, Department of Medicine, Nanchang University (NO. PY201808).

\section{Authors' contributions}

HW conceived of the study and participated in its design, as well as contributed to the analysis and interpretation of data and drafted the manuscript. LC contributed to the study design, and participated in the data collection and helped to revise the manuscript. TZ contributed in the data sorting and participated in the data collection and quality control of the data. ZZ contributed to the data collection and participated in the data sorting. CZ were involved in the data collection and analysis. All authors read and approved the final manuscript.

\section{Acknowledgments}

We would like to thank all the participants for their contributions to the present study as well as the specialists without whose support the present study would not have been completed. Also, we wish to thank the editor, the associate editor, and the three anonymous reviewers for their helpful comments and suggestions, which have led to an improvement of this article.

\section{References}


1. El-Serag HB, Rudolph KL. Hepatocellular carcinoma: epidemiology and molecular carcinogenesis. Gastroenterology. 2007;132:2557-76.

2. Global Burden of Disease Cancer Collaboration. Global, regional, and national cancer incidence, mortality, years of life lost, years lived with disability, and disability-adjusted life-years for 32 cancer groups, 1990 to 2015: a systematic analysis for the global burden of disease study. JAMA Oncol. 2017;3:524-48.

3. Ozakyol A. Global epidemiology of hepatocellular carcinoma (HCC epidemiology). J Gastrointest Canc. 2017;48:238-40.

4. Llovet JM, Burroughs A, Bruix J. Hepatocellular carcinoma. Lancet. 2003;362:1907-17.

5. Farazi PA, DePinho RA. Hepatocellular carcinoma pathogenesis: from genes to environment. Nat Rev Cancer. 2006;6:674-87.

6. Yang JD, Roberts LR. Hepatocellular carcinoma: a global view. Nat Rev Gastroenterol Hepatol. 2010;7:448-58.

7. Park JW, Chen M, Colombo M, Roberts LR, Schwartz M, Chen PJ, Kudo M, Johnson P, Wagner S, Orsini LS, Sherman M. Global patterns of hepatocellular carcinoma management from diagnosis to death: the BRIDGE Study. Liver International. 2015;35:2155-66.

8. Kew MC. Epidemiology of chronic hepatitis B virus infection, hepatocellular carcinoma, and hepatitis B virus-induced hepatocellular carcinoma. Pathol Biol (Paris). 2010;58:273-7.

9. Custer B, Sullivan SD, Hazlet TK, lloeje U, Veenstra DL, Kowdley KV. Global epidemiology of hepatitis B virus. J Clin Gastroenterol. 2004;38:158-68.

10. Yang JD, Mohamed HA, Cvinar JL, Gores GJ, Roberts LR, Kim WR. Diabetes mellitus heightens the risk of hepatocellular carcinoma except in patients with hepatitis c cirrhosis. Am J Gastroenterol. 2016;111:1573-80.

11. Wild CP, Gong YY. Mycotoxins and human disease: a largely ignored global health issue. Carcinogenesis. 2010;31:71-82.

12. Sudakin DL. Dietary aflatoxin exposure and chemoprevention of cancer: a clinical review. J Toxicol Clin Toxicol. 2003;41:195-204.

13. Morgan TR, Mandayam S, Jamal MM. Alcohol and hepatocellular carcinoma. Gastroenterology. 2004;127:87-96.

14. Seitz HK, Stickel F. Risk factors and mechanisms of hepatocarcinogenesis with special emphasis on alcohol and oxidative stress. Biol Chem. 2006;387:349-60.

15. Park JW, Chen M, Colombo M, Roberts LR, Schwartz M, Chen PJ, Kudo M, Johnson P, Wagner S, Orsini LS, Sherman M. Global patterns of hepatocellular carcinoma management from diagnosis to death: the bridge study. Liver Int. 2015;35:2155-66.

16. Yang JD, Hainaut P, Gores GJ, Amadou A, Plymoth A, Roberts LR. A global view of hepatocellular carcinoma: trends, risk, prevention and management. Nat Rev Gastroenterol Hepatol. 2019;16:589-604.

17. Jee SH, Ohrr H, Sull JW, Samet JM. Cigarette smoking, alcohol drinking, hepatitis B, and risk for hepatocellular carcinoma in Korea. J Natl Cancer Inst. 2004;96:1851-6.

18. Chen ZM, Liu BQ, Boreham J, Wu YP, Chen JS, Peto R. Smoking and liver cancer in China: case-control comparison of 36,000 liver cancer deaths vs. 17,000 cirrhosis deaths. Int J Cancer. 2003;107:106-12.

19. Zhu K, Moriarty C, Caplan LS, Levine RS. Cigarette smoking and primary liver cancer: a population-based case-control study in US men. Cancer Causes Control. 2007;18:315-21.

20. Lee YCA, Cohet C, Yang YC, Stayner L, Hashibe M, Straif K. Meta-analysis of epidemiologic studies on cigarette smoking and liver cancer. Int J Epidemiol. 2009;38:1497-511.

21. Sobin LH, Wittekind CH. Urological tumours. In: Sobin LH, Wittekind CH, editors. TNM Classification of Malignant Tumours. 6th ed. New York: Wiley-Liss; 2002. pp. 199-202.

22. Flaman JM, Frebourg T, Moreau V, Charbonnier F, Martin C, Chappuis P, Sappino AP, Limacher IM, Bron L, Benhattar J, Tada M, Van Meir EG, Estreicher A, Iggo RD. A simple p53 functional assay for screening cell lines, blood, and tumors. Proc Natl Acad Sci USA. 1995;92:3963-7. 
23. Lehmann-Che J, André F, Desmedt C, Mazouni C, Giacchetti S, Turpin E, Espié M, Plassa LF, Marty M, Bertheau P, Sotiriou C, Piccart M, Symmans WF, Pusztai L, de Thé H. Cyclophosphamide dose intensification may circumvent anthracycline resistance of p53 mutant breast cancers. Oncologist. 2010;15:246-52.

24. Schmitz PIM. Statistical methods in cancer research, 2001; Vol 1: The analysis of case-control studies. IARC.

25. Petitjean A, Mathe E, Kato S, Ishioka C, Tavtigian SV, Hainaut P, Olivier M. Impact of mutant p53 functional properties on TP53 mutation patterns and tumor phenotype: lessons from recent developments in the IARC TP53 database. Hum Mutat. 2007;28:622-9.

26. Cho Y, Gorina S, Jeffrey PD, Pavletich NP. Crystal structure of a p53 tumor suppressor-DNA complex: understanding tumorigenic mutations. Science. 1994;265:346-55.

27. Meinhold-Heerlein I, Ninci E, Ikenberg H, Brandstetter T, Ihling C, Schwenk I, Straub A, Schmitt A, Bettendorf H, Iggo R, Bauknecht T. Evaluation of methods to detect p53 mutations in ovarian cancer. Oncology. 2001;60:176-88.

28. Watanabe J, Nishiyama H, Okubo K, Takahashi T, Toda Y, Habuchi T, Kakehi Y, Tada M, Ogawa O. Clinical evaluation of p53 mutations in urothelial carcinoma by IHC and FASAY. Urology. 2004;63:989-93.

29. Chappuis PO, Estreicher A, Dieterich B, Bonnefoi H, Otter M, Sappino AP, Iggo R. Prognostic significance of p53 mutation in breast cancer: frequent detection of non-missense mutations by yeast functional assay. Int J Cancer. 1999;84:587-93.

30. deVerre White RW, Deitch AD, Gumerlock PH, Shi XB. Use of a yeast assay to detect functional alterations in p53 in prostate cancer: review and future directions. Prostate. 1999;41:134-42.

31. Wang H, Liao P, Zeng SX, Lu H. It takes a team: a gain-of-function story of p53-R249S. J Mol Cell Biol. 2019;11:277-83.

32. Wong GS, Lee JS, Park YY, Klein-Szanto AJ, Waldron TJ, Cukierman E, Herlyn M, Gimotty P, Nakagawa H, Rustgi AK. Periostin cooperates with mutant p53 to mediate invasion through the induction of STAT1 signaling in the esophageal tumor microenvironment. Oncogenesis. 2013;2:e59.

33. Gelatti U, Covolo L, Talamini R, Tagger A, Barbone F, Martelli C, Cremaschini F, Franceschi S, Ribero ML, Garte S, Nardi G, Donadon V, Donato F. N-Acetyltransferase-2, glutathione S-transferase M1 and T1 genetic polymorphisms, cigarette smoking and hepatocellular carcinoma: a case-control study. Int J Cancer. 2005;115:301-6.

34. La Vecchia C, Negri E, DeCarli A, D’Avanzo B, Franceschi S. Risk factors for hepatocellular carcinoma in northern Italy. Int J Cancer. 1988;42:872-6.

35. Szymańska K, Lesi OA, Kirk GD, Sam O, Taniere P, Scoazec JY, Mendy M, Friesen MD, Whittle H, Montesano R, Hainaut P. Ser-249TP53 mutation in tumour and plasma DNA of hepatocellular carcinoma patients from a high incidence area in the Gambia, West Africa. Int J Cancer. 2004;110:374-9.

36. Camplejohn RS, Rutherford J. p53 functional assays: detecting p53 mutations in both the germline and in sporadic tumours. Cell Prolif. 2001;34:1-14.

37. Paget V, Sichel F, Garon D, Lechevrel M. Aflatoxin $B_{1}$-induced TP53 mutational pattern in normal human cells using the FASAY (Functional Analysis of Separated Alleles in Yeast). Mut Res. 2008;656:55-61.

\section{Figures}


A

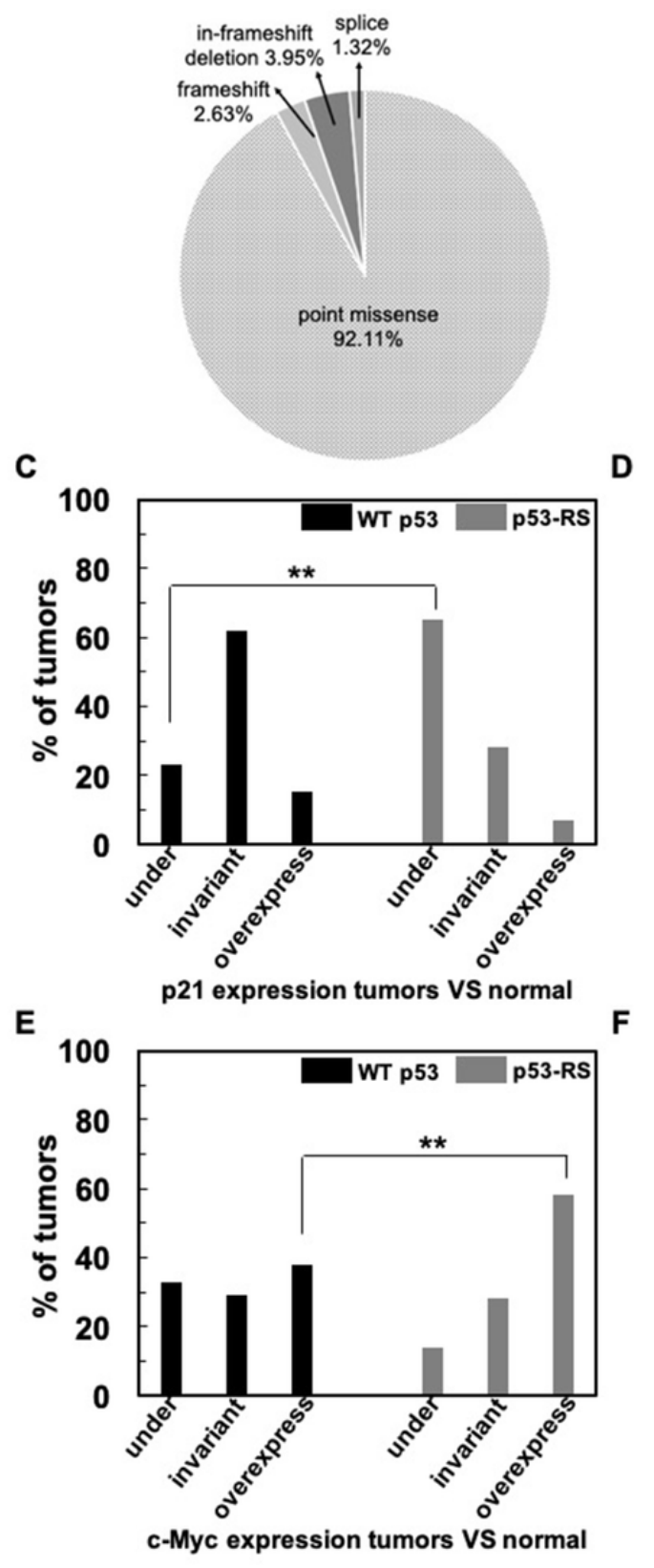

B
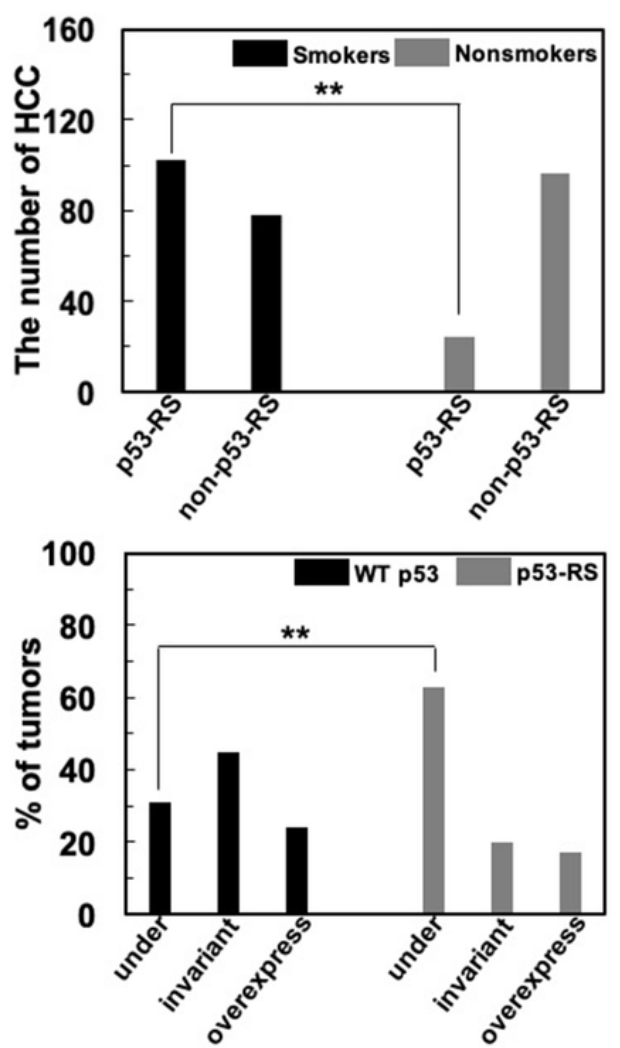

Bax expression tumors VS normal

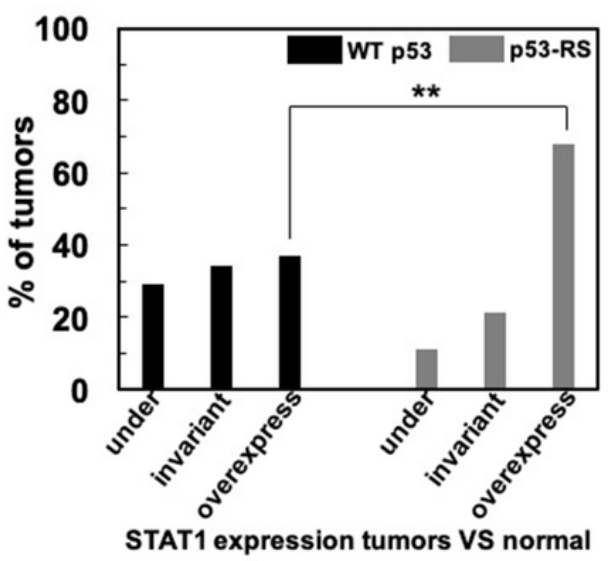

Figure 1

Distribution of TP53 and Effect of p53-RS mutations on expression of p53 and p53-RS targeted genes. A: Repartition of the TP53 mutations among mutated cases. 210-point missense mutations were observed among 228 mutation cases ( $92.11 \%)$. 18 cases showed three other mutations: 6 frameshift mutations $(2.63 \%)$ along with 9 in-frameshift deletion mutations (3.95\%), 3 splicing mutations (1.32\%). B: Number of HCC in p53-RS and non-p53-RS between smokers and nonsmokers (**p < 0.001). C-F: Variation of the expression of Bax and p21, as well as c-Myc and STAT1 in the WT p53 and p53-RS groups of tumors, evaluated by qRT-PCR (**p < 0.001). (C): p21; (D): Bax; (E): c-Myc; (F): STAT1.

\section{Supplementary Files}

This is a list of supplementary files associated with this preprint. Click to download.

- WangHSTROBEChecklist.doc 
- SupplementaryTable2.doc

- SupplementaryTable1.doc 